\title{
SOUNDING SILENCE: INSPIRATION AND PASSIVENESS IN THE READING OF EARLY MODERN WOMEN
}

\author{
Daniel Essig García, Universidad Autónoma de Madrid \\ Email: daniel.essig@uam.es
}

\begin{abstract}
Cultural and material change described by historians of reading intersects with literary history in different and complex ways. An example is the cultural practice of silent reading in intimacy, which came to be pivotal for the literature of sensibility. It was gendered female in the eighteenth century and looked upon with disfavour, notably by moralists and pedagogues. However, not very long before, silent reading was associated with spirituality and women's religious experiences, and was compatible with the virtues expected of the "lady of the Renaissance". Several texts from the seventeenth century, notably diaries by women, will be discussed.
\end{abstract}

Keywords: women's studies, aesthetics, intellectual history, religious cultural groups, art history, reader text relationship, silent reading, diaries.

Título en español: "Resonancia del silencio: inspiración y pasividad en la lectura femenina en el siglo XVII".

Resumen: Los cambios culturales y materiales que describe la historia de la lectura entran en relaciones variadas y complejas con la historia literaria. Un ejemplo de esa dialéctica es la evolución de la práctica de la lectura silenciosa en recogimiento, que alcanzó una importancia extraordinaria para la novelística del Dieciocho. Se consideraba propia de las mujeres y estaba mal vista por moralistas y pedagogos. No mucho antes, empero, la lectura en silencio había sido un componente de la experiencia espiritual y religiosa de la mujer del Renacimiento, y como tal compatible con las virtudes femeninas. El artículo incluye comentarios de varios textos del diecisiete, en particular diarios de mujeres.

Palabras clave: (traducidas del tesauro de ERIC): estudios de la mujer, estética, historia intelectual, grupos culturales religiosos, historia del arte, relación entre lector y texto, lectura en silencio, diarios.

Jean Starobinski pointed out long ago that a powerful icon of the new individuality in the second half of the eighteenth century was the "inner animation" ("mouvement suspendu [...] animation intérieure") and the absorption shown by the subjects in portraits of women reading, alone (Starobinski 1964: 113). Much has been made of the efficiency of such images, both by art historians, 
Those states and activities are also to be understood as vehicles of absorption. In fact it is only in the context of the primacy of absorption in the painting and criticism of the period that the latter works become expressively, as opposed to merely iconographically, intelligible - that their peculiar, almost unfathomable mood of lassitude, reverie, and psychological absence can be seen as other than aberrant (Fried 1980: 35).

and, more tentatively, by literary critics, ${ }^{50}$

Anyone surveying the Dutch and French genre paintings and prints of the seventeenth and eighteenth century - a type of image making that captures ordinary people in their everyday domestic activities - will quickly discover the currency of images of readers reading. From old men reading grand folios in solitude to young women absorbed in their novels, the paintings and prints of the period stage reading as inviting, compelling, and sometimes dangerous. They document the period's fascination with what was after all still a relatively new activity, one which, with the spread of literacy, was becoming an increasingly important part of everyday life. These images do not merely reflect a struggle around literacy happening else $\cdot$ where; instead, these images are themselves part of a critical debate that developed, over the course of the early modern period, about how reading influences readers. What started as a promotional campaign for the reading of moral and didactic books ends up as a culture war about the pleasures and dangers of novel reading (Warner 2000: 393).

The power of those widespread icons has much to do with the way in which they capture the onlooker's attention with their combination of passivity and absorption..$^{51}$ Painters started producing those images at a time when new languages ${ }^{52}$ of passivity and sensibility had acquired enormous prestige; so it may be useful to query whether some of the elements of the equation thus bringing together subjectivity, passiveness, and the aesthetic of absorption can be shown to have been already in place $c .1660$. The ways in which eighteenth-century portraiture evolved - including the surprising but accurate observation that in eighteenth-century British portraits of men from the nobility and the gentry, and even the merchants that aped their manners, books are absent (Sharpe and Zwicker 2003: 17) - are partly the result of a slow and protracted re-evaluation of the social and cultural practice of silent reading, notably among women: formerly seen as a necessity imposed, that practice became a pleasurable opportunity for introspection and exploration of the self in solitude. Furthermore, for a brief period after 1642 and the onset of civil violence in the British kingdoms, reading in silence offered people an opportunity for reacting in a heterodox manner to texts - for example, the Book of Revelation, or some of the prophetic books of the Old Testament - which had not been traditionally considered quite appropriate

50 The ground-breaking study in that field was William Beatty Warner's "Staging Readers Reading," Eighteenth-Century Fiction, Volume 12, Number 2-3 (January-April 2000): [392]-416.

51 The argument was developed by Michael Fried.

52 I am using throughout the word "languages" in plural in John Greville Agard Pocock's and Quentin Skinner's sense. "To take the former first, what are the languages of which I speak in the plural, and how does one reconstitute them? [...] [I]n the early-modern period (1500-1800) it is especially useful to say that there was not just one specialized language of political thought [...] but a number of them; and that these were located in and derived from the activities of a number of specialized professional groups." (Pocock 2009: 111). See also "The Concept of a Language and the métier d'historien: some considerations on practice," Pocock 2009: 87-105. 
for "gentle readers", (that is, women). It is interesting to explore the possibility that there might have been a degree of continuity, from inspired reading - and writing - in the 1640s and 1650 s to the reading of curiosity in the age of the pioneers of experimental philosophy (from 1650 to 1687, the year of publication of Newton's Principia Mathematica) and further on to the new understandings of passivity in the age of politeness and sentimental reading (from the publication of Anthony Ashley Cooper, $3^{\text {rd }}$ Earl of Shaftesbury's Characteristics of Men, Manners, Opinions, Times in 1710 to the accession of George III in 1760).

More generally, after decades when historians of Modernity placed the stress on the study of individual authors (the lives and ideas of "great men" like Descartes or Newton) $)^{53}$, attention has shifted over the past thirty years to humbler and more patient narratives: notably, the history of practices, and material culture, is proving crucial. Of paramount interest for us are changes in reading practices and in material culture as pivotal factors in the formation of modernity. ${ }^{54}$ In other words, a shift is perceptible away from Whig, or teleological, narratives ${ }^{55}$; for example, nuanced approaches stressing the evolution in the language of gender which led to the complex and subtle interplay of sympathy, identification, and guilt in Samuel Richardson's novels Pamela (1740) and Clarissa (1748) and the novels of sentiment at large.

The fashion for portraits of women reading in isolation and intimacy was deeply ambiguous ${ }^{56}$ like that for sentimental novels. Despite the glamour, powerful cultural prejudices come to the fore with such images: mainly an enduring suspicion of women in intimacy. But what was disquieting in images of women reading in silence, solitude or tranquillity? How did such practices of reading come to be censored in the central decades of the eighteenth century (only indirectly in the case of Samuel Richardson, but more clearly in writings of innumerable moralists and in the works of didactic commentators)? To those questions, the study of the genealogy of sensibility provides suggestive answers, foremost among them that the memory of the traumas of the 1640s and the 1650s in the British kingdoms was alive: the belief that part of the causes of the civil wars was the loss of control over subjects who, despite their apparent passiveness and acquiescence, could be suspected or accused of questioning, even rejecting, the submission of the Christian person's religious experience to the laws of the secular state.

My central claim here will be that in the closing decades of the seventeenth century, silent reading was reinterpreted and reassessed, thus paving the way for a new conception of passivity, associated with sensibility. This involved re-evaluations of the gendering of

53 For a powerful critique of such accounts, see Stephen Toulmin, Cosmopolis: The Hidden Agenda of Modernity (Chicago: Chicago University Press, 1990).

54 See McKeon 2005; Roberts, "Shakespeare 'creepes into the womens closets about bedtime': Women Reading in a Room of their Own," in Renaissance configurations: voices/bodies/spaces, 1580-1690, ed. Gordon McMullan (London: Macmillan, 1998): 30-63; Warner 2000.

55 Those alternative genealogies begin by positing the significance of such supposedly male precincts as the Royal Society, the coffeehouses, the new trades in "the marketplace of print" and publication, as well as the presence in them of at least partly independent women.

56 For example, Jean-Honoré Fragonard's Jeune fille lisant (Washington, National Gallery of Art), Sir Joshua Reynolds's Theophila Palmer Reading Clarissa (private collection), Pierre-Antoine Baudoin's La Lecture (Paris, Musée des arts décoratifs), or, slightly older, Jean Raoux's Jeune fille lisant une lettre (Paris, Musée du Louvre). 
reading practices: reading in silence by women, which did not awake remarkable anxiety in the sixteenth century (Hackel 2003: 112-3), had by 1750 come to be perceived as ambivalent and even disturbing.

After the introductory section one, section two ("The Annunciation, or silent reading enacted; the utopia of female passivity") will briefly discuss reading by women as it was perceived and represented in the Renaissance, together with the spiritual implications of such representations. Section three ("The scold and the civil war vs. the "weaker vessel'") will look at an almost schizophrenic division induced into male writers and moralists by the co-existence of the characters of the scold and the shrew in early modern Europe, alongside the metaphor of Woman as the "weaker vessel". Section four ("Images of passive reading") will explore the aporias of the conceptual-analytical category active reading; it will also consider the rise of new ideas of passivity in the first half of the eighteenth century.

\section{THE ANNUNCIATION, OR SILENT READING ENACTED; THE UTOPIA OF FEMA- LE PASSIVITY}

What, then, could have been the prehistory of the eighteenth-century male fear of women reading in privacy or even secrecy (commonly, such "secrecy" was a male fantasy)? Those subjects, as a result of their absorption, are radically passive: in our definition of passiveness they are perceived as being inert, in appearance they do not show any sign of passion. In the early modern language of ethics and psychology, however, things are more complicated, as is made clear by the history of the noun "passion" and the adjective "passive" 57 . The early modern use of the word "passions" was different from ours, first, in that it is commonly plural. Defined and described as a complex classificatory system:

The seventeenth century inherited a long and palimpsestic list of affections which served as a form of definition of the passions. No one could ignore the fact that among the principal examples were joy and distress in their many forms; hope, fear, and their variant; and desires in all the diversity. To enumerate these affections was thus one way of explaining what the category included, and interpretations of the category where in turn elaborated in the light of this canonical list (James 1998: 913).

The Renaissance language of the passions, powerfully influential, and evolving in a complex dialogue between the philosophies of Greco-Roman antiquity and Christianity, reached its greatest subtlety in the aftermath of the Reformation and the climax of the European wars of religion. The oddness of semantic evolution here - "passive" is not to

57 The bibliography on the subject is enormous. To mention only a handful of examples: Mark Greengrass, Governing Passions. Peace and Reform in the French Kingdom, 1576-1585. (Oxford: Oxford University Press, 2007); Albert O. Hirschman. The Passions and the Interests. Political Arguments for Capitalism before its Triumph. (Princeton: Princeton University Press, 1977); Susan James, "Passions in Metaphysics;" Susan James, Passion and Action. The Emotions in Seventeenth-Century Philosophy. (Oxford: Oxford University Press, 1997); Anthony Levi, French Moralists. The Theory of the Passions, 1585 to 1649. (Oxford: Oxford University Press, 1964); Michel Meyer, Le Philosophe et les passions. Esquisse d'une histoire de la nature humaine (Paris: Presses Universitaires de France, 1991); Gerhard Oestreich, Neostoicism and the Early Modern State. (Cambridge: Cambridge University Press, 1982); Carole Talon-Hugon, Les Passions (Paris: Armand Colin, 2004); Richard Tuck, Philosophy and Government. 1572-1651. (Cambridge: Cambridge University Press, 1993). 
"passion" as "active" is to "action" - suggests some conceptual knot, visible in historicalphilosophical terms: in that general context of the passions and civil war, models where a passion like wrath was combined with intemperance, pride, etc., were commonly invoked to explain religious violence.

The subjects under the empire of such passions were understood to be legible, in a tradition in which the passions were represented allegorically by their ostensible effect on the body. The result is an iconography aimed at exposing the passions, one which is the exact opposite of such representations of peaceful reverie and introspection in the eighteenth century, most famously Jean-Honoré Fragonard's Jeune fille lisant in the National Gallery of Art (Washington). The emphasis on visibility and legibility means that from the Neo-Stoics to Charles Le Brun passions like wrath were given pride of place, as opposed to, for example, curiosity.

On the other hand, commentators were intrigued by the possibility that a person, under the empire of passions such as curiosity or jealousy, might not seem passionate. Now, in the case of subordinate persons, from a lower social status, an important corollary to the norms to which they were supposed to obey was that as long as nothing was visible, expressed externally, as long as no alteration was perceptible, there was no reason to suspect concealed emotions or affects: they simply did not exist. The inner emotions of subjects like those were discountable, and therefore of little concern for moralistic writers. In the case of women, manuals for their education made it clear: silence, obedience, and chastity were considered the most important characteristics of a good wife. If we look at this with eyes innocent of cultural history, armed only with supposed common sense, it is strange to find broaches to the law of silence put on a par with offences against chastity. Again, one rightly suspects a conflict of meanings here. The epithets, "silent, obedient, and chaste", ${ }^{58}$ are not merely Renaissance clichés; they are extremely precise: what happens is that infringements to those rules stand in a metonymical relation; faults against silence are (minor) offences against chastity, and of course they are made audible, and hence they cannot be ignored. Conversely, if reading in silence or silent reading was considered in the 1700 s an innovative and disturbing practice, it was supposed to suit the lady of the Renaissance perfectly well: she was indeed, when reading silently in intimacy, silent, obedient, and chaste.

In the early stages of the evolution of that theme, a strangely anachronistic, and delightful, icon came to the fore: the Annunciation. Not invariably but very commonly, the Virgin Mary is portrayed with a small book in her hands ${ }^{59}$; alternatively, the small volume is placed on a bookstand, or again, sometimes the stand is vacant. Mary with her book brings together the three crucial qualities of the Christian woman: she is obedient to God ("Ecce ancilla Domini"), father and husband figure; she is chaste beyond ordinary nature, which dictates that even in matrimonial chastity, conception must come about by and after sex; she

58 See Suzanne W. Hull: 1982.

59 Typically, a book of hours in 8 vo or $12 \mathrm{mo}$ format. The list is long of Annunciations where Mary is shown with a book in her hands, or generally close to her; to mention some of them: Masolino's (Washington, National gallery of Art), Duccio's (National Gallery, London), Lorenzetti's (Sienna, Pinacoteca nazionale), Tadeo Gaddi's (Museo Bandini a Fiesole), Giovanni dal Ponte's in Pratovecchio (Badia di Santa Maria a Poppienna), Del Biondo's (Florence, Ospedale dei Innocenti), Monaco's (Florence, Santa Trinità), Fra Angelico's at Cortone, at San Giovanni Valdarno, Lippo Lippi's in the Methuen Collection (Corsham Court), Lippi's again at the National Gallery (London). All those examples are taken from Daniel Arasse's L'Annonciation italienne: une histoire de perspective (Paris : Hazan, 1999). 19, 62, 75, 109, 116, 121, 122, 135, 141, 149, 155. 
only speaks when spoken to (she has become the patient of a speech act, an annunciation); one readily imagines that silence is her ordinary demeanour. One plausible explanation for the presence of the book and bookstand is that they are there in order to make perspective more perceptible and vivid. As opposed to readers in eighteenth-century European painting, Mary is generally not shown to be concentrating in her book. ${ }^{60}$

Lay religious women, who were often members of the elites, felt that silent reading allowed them to cultivate interiority and spirituality, the basis of individual piety: the stress came to be placed on inspiration in silence and the reception of the word of God. Emphasizing reception, in turn, underlined the practice of individual reading. Among the long list of examples that can be given, this is taken from the diary of Lady Margaret Hoby, which she kept in the last years of Elizabeth I's reign and the beginning of the Jacobean period; among other things, there is a clear confluence between the reading of the Bible, the writings of the self, and solitude and intimacy: "this day I beinge not well praied and reed in mine owne chamber" (Hoby 1997: 69) ${ }^{61}$,"after privatt praers I reed of the bible and then went to worke after I dined" (1997: 70), "this day I kept my chamber and as I was able I wrought and reede" (1997: 71); "after I had reed and praied I went about the house" (1997: 73), "after I praied and reed and wrett notes in my bible of the morninge exercise" (1997: 74).

The claim that women occupy a privileged site which empowers them to understand and share in the direct experience of Christ, and that in doing so they speak on behalf of humanity as a whole, was the last of the great Renaissance utopias, and arguably the most powerful (from the law-abiding Beguines to the more unsettling Familists and the prophets in the 1650s, the decade of the Quakers in England):

The last advantage of woman over man to be considered here is solely the feature of the Renaissance, although it is consistent with the advantages considered already. Marsilio Ficino's attempt to marry Plato and theology leads him to a reconsideration of divine love which conduces greatly to the honour of the female sex, and it is a commonplace that in the Renaissance, woman was exalted by neoplatonist theory. Love is the vinculum mundi binding the whole of creation together; earthly love is a step on the ladder of love leading eventually to ecstatic reunion with the Godhead. When a woman is loved, her lover is loving not only her, but God and himself as well. The perfection of love is in reciprocity; but its origin lies in beauty which women possess in greater store than men. Physical beauty reflects mental goodness; thus women are better than men. Furthermore, the being least weighed down with earthly matter is the most spiritual, and its soul is more free to escape from the fetters of physical existence; women therefore are able more easily to transcend the limitations of this world (Maclean 1980: 24).

\section{THE SCOLD AND THE CIVIL WAR VS. THE "WEAKER VESSEL"}

Silence, in short, was gendered ("The production of language was a site of particular contest in the definition and prescription of womanhood with which so many writers were concerned. Woman's verbal restraint was one of the cornerstones of virtue" (Jardine 1983:

60 Lipo Lippi's at National Gallery is an exception, with the Virgin's ambiguous gaze. Mary in Botticelli's Annunciation in the Lehman Collection, Metropolitan Museum of Art (New York), on the other hand, is actually looking at her book from very close (Arasse, Annonciation, 203).

61 Quotations from Hoby will respect her spelling and (lack of) punctuation. 
104)); it was appropriated by women: somehow it was often treasured by them, just as it was understood to be their duty. But why was it so vital? One has to look for the answer to that question in the murky terrain of misogynous discourse as it concerned itself with the "tongue," speech or voice of women, and what was seen as its frightening power. In the words of Lisa Jardine and Dagmar Freist:

There is a disturbing consensus amongst this varied sources as to the unacceptable emasculating, and yet curiously seductive nature as such female attributes. If the definition of the virtues wife is as chaste, obedient, dutiful and silent, then the definition of the wife without virtue is as lusty, headstrong and talkative. These qualities make her both provocative and threatening. Woman's moist humours, which make her lascivious, also loosen her tongue. The tongue is symbol of impudence, that is, immodesty, to be carefully covered by the teeth (so gentlewomen are advised) (Jardine 1983: 104).

The free utterance of opinions by women was equated with sexual looseness and disorder. [...] The image of the seductress evoked here introduces the irrational, incomprehensible, and uncontrollable in women as it was seen by many male contemporaries. The power of women's free speech is intertwined with their "overpowering" sexual lust and desire, which men often felt to be threatening. This perception of women's unguarded speech is reinforced by the focus on the female tongue as a woman's main strength (Freist 1997: 286).

Practically everything connected to the passions was a cause of terror for early modern men, and the relation between the passions and gender was paramount in those fears. However, it would be an oversimplification to think of some passions as being exclusively "feminine", to see the system of passions statically as a binary system of gendered opposites. The essentially dynamic configuration of the passions in the Early Modern period meant that the passions did not solely inhabit an individual, gendered, body in our modern sense: the war of the passions (including not just the war between the passions and reason, but also wars between rival passions) could be witnessed in (a) an individual, gendered body, but also (b) in the community or polity, in the body politic ${ }^{62}$. The idea of the body politic, which disappeared slowly in the course of the seventeenth century, was more than a mere metaphor.

The effect of women's tongues could be devastating. The dynamic conception of the body, and the commonwealth, as a theatre of war for the passions explains the mortal anxiety about war, wars of religion, and more precisely civil war. Civil war was both an oxymoron and a constant threat. The body, beyond or not up to individuality, was seen as the battlefield of warring passions: civil war, which was a cause of constant terror. In the chain of metaphors that joined kingdom or state, and the human body, the visions of family and marriage were important links, and they were, understandably, also polemic: it therefore makes sense to imagine the rule or empire of the passions - some later gendered and related to women - as being a constant threat to social and psychological equilibrium or balance.

62 Among the many treatments of the theme, one which connects the extended metaphor of the body politic with reading is Michael Schoenfeldt, "Reading Bodies," in Reading, Society, and Politics in Early Modern England, eds. Kevin Sharpe and Steven Zwicker (Cambridge: Cambridge University Press, 2003), 215-243. 
This is conspicuous in the widespread obsession with verbal violence by women, which was considered both as cause and part of civil violence and disorder. As mentioned above, offences by "imperfect" Woman against the law of silence were in fact infringements of the duty of chastity. Of course, norms deal with perceived threats: in this particular case, that of the verbally aggressive woman, the "scold". Shakespeare's The Taming of the Shrew may look ridiculous to us: but Elizabethans were indeed very serious about verbal incontinence. They took that prejudice to extremes of virulent misogyny (not in Shakespeare but, for example, in Joseph Swetnam's Arraignment of Lewd, Idle, Froward and Unconstant Women, 1615): Lisa Jardine quotes contemporary satire comparing the tongues of women with the penis (Jardine 1983: 121-5); Dagmar Freist also pointed out the association in her book Governed by Opinion (Freist 1997: 282-8).

This misogynous prejudice can be read in the pen of even moderate Protestant men: In this wise shee shall make election and choise of that whiche she ought to keepe silent setting a lawe to her self, to doe the one and eschue the other, for she ought to know that the use of the toung is to be used soberly and discretly, for to that ende nature, that wise woorke woman ordained the toung to bee inclosed as with a hedge within twoo rowes of teeth, where contrarie shee hath leaft our eares open, the one to be readie to heare and the other slowe to speake (Salter 1997: 49) ${ }^{63}$.

In a nutshell, what we find in such topoi is a fear that the verbal aggressiveness which women were prone to ${ }^{64}$ - the voicing of "opinion", a word which was derogatory in those times - might endanger the peace of the kingdom. Men gave expression to an almost magical belief in the power of female speech or voice, according to which insults and sexual slander by verbally violent women were equivalent to body blows. Chapter 5 of Jonathan Gil Harris's Foreign Bodies and the Body Politic proposes a general vision and survey of the theme which invokes the figure of the witch:

The threat of the witch's tongue was thus three-fold. Not only did it speak (and spread) the poisonous language of "secret societies" diabolically opposed to the written authority of scripture; it also spoke out in "shrewish" fashion against patriarchal authority; and finally, it endangered, by means of spoken (or muttered) charms and curses, the safety of Christians and Christian society (Harris 1998: 120).

Nonetheless, in sheer contradiction with the misogynous early modern obsession about the threat posed by Woman's voice or tongue, certain Biblical texts dear to Protestants were much more ambivalent about the whole question of humility, silence, and speech. The key to that was a phrase taken from Tyndale's English version of the New Testament, specifically St. Peter's epistle to the Ephesians (Fletcher 1995: 60), where women are described as the "weaker vessel". This demanded and challenged interpretation. In orthodox Protestantism, whose ideas of women were anyway highly contradictory, the weaker vessel might well store and treasure an essence which ought to be recognized as the word of God, serve as container and duct from which the Word might be poured. One result of that is a critique of

63 Quotations from Salter respect his spelling.

64 On the social history of this, see Gowing 1996. 
the supposed duty of feminine silence: it cannot be a duty, if it is in the nature of women; more importantly, breaches of the duty of silence might be desirable given that God sometimes speaks through women. The rationale behind such anti-misogynous interpretation would be this: because women were said to be intellectually and psychologically weaker, because they have been disciplined to remain silent, God's word in their mouths will remain comparatively pure, and thence God prefers to speak through the voice of Woman:

Prophecy contravenes the prohibition of speech, teaching and preaching by women: it reflects one aspect of a further prerogative of women over man, which is only conducive to her honour in a rather doubtful way. If woman is generally considered to be weaker than men, her virtuous acts become as a consequence much more admirable, since the gap between her action and her true nature is greater than the same gap in a man. [...] The evocation of a disproportion of acts and agent is found notably in Peter Abelard's hymns in the medieval period. Other scholastic writers also dwell on this paradox of strength in weakness (Maclean 1980: 21).

Another factor playing in the same direction was the notion of "inspiration" - alongside its near synonym "enthusiasm" - which came from Greek literary theory and was pivotal for a number of authors, in the English tradition for example Philip Sidney and Edmund Spenser. Now, an interesting by-side element in these theories, or rather themes, was that the more passive - the adjective could mean "receptive" - the vessel, the better. That train of thoughts both strengthened the association between women and prophecy, and also placed positive value on passiveness. Passiveness and its manifold consequences are connected to Woman's particular advantages in the field of religious experience.

Those arguments provide a running thread in the history of the religious experiences of Western women, leading to the utopia mentioned in the preceding section; that thread brings together the role of women in the formation of sects, the association of silence and the sacred, the intensity of religious experience and expression in women: in interpretation, the humbler the vessel, the more valuable her word. More precisely, the new appreciation of those Christian themes suggested that the punctual voice of the (male) theological interpreter, including its articulation as writing, sometimes should be silenced to the greater glory of God; that silence is tantamount to a more profound communication with God and His voice.

Or, from a different perspective: the reading of the Scriptures in the vernacular made those texts which, in one way or another, came from God, more self-sufficient, self-contained, or closed. In that case, only God's ulterior voice - through the inspired prophet - is justified to gloss those divine texts in the human world. Silence is reinterpretation, and silence best accompanies inspiration.

In summary, women reading in silence, so fascinating and disturbing in the eighteenth century, would not have been so conspicuous in the "age of the passions", the sixteenth and the seventeenth century. Descartes, for example, could hardly have linked women reading in intimacy to the violent passions (think of the reality of war, and wrath, or anger; those were not, for men in the seventeenth century, feminine passions). 


\section{IMAGES OF PASSIVE READING}

If public speech by women could be justified by a radical construction of the theme of the weaker vessel, how much more could private reading be. According to the notion of inspired reading, the bugbear of the Royal Society in the 1660s (Johns 1998: 386-428; Heyd 1995: 144-164), the woman preacher explains publicly what has been revealed to her in her private reading in solitude. It is, arguably, the most perfect modelling of intensive reading.

The meshing of reading and public speech by women was denounced by enemies of the sects:

After this speech she made a prayer for almost half an hour, and after her prayer took that Text, If ye love me, keep my Commandements [John 14:15]; when she had read the Text, she laboured to Analyze the Chapter as well as she could, and then spake upon the Text, drawing her Doctrines, opening them, and making two uses, for the space of some three quarters of an hour: when she had done she spake to the company, and said, if any had any thing to object against any of the matter delivered, they might speak (Edwards 1997: 153).

as opposed to an admiring husband describing his wife's reading:

For [Katherine Stubbes's] whole heart was bent to seeke the Lorde, her whole delight was to bee conversant in the Scriptures, and to meditate upon them day and night [Ps. 1: 2]: insomuch that you could seldome or never have found her without a Bible, or some other good booke in her hands. And when she was not reading, she would spend the time in conferring, talking and reasoning with her husband of the worde of God, and of Religion: asking him: what is the sence of this place, and what is the sence of that? Howe expounde you this place, and howe expounde you that? What observe you of this place, and what observe you of that? So that shee seemed to bee, as it were ravished with the same spirit that David was, when hee saide, The zeale of thy house hath eaten me up [Ps. 69: 9] (Stubbes 1997: 58).

The re-appraisal of women's inner spirituality and of their potential for religious feeling came with a cost: that is, the tradition of criticism and satire of Enthusiasm ${ }^{65}$. Enthusiasm, or divine inspiration, was condemned by Anglican High Church theologians and educators, treated like a spiritual ailment; and one of the possible causes of Enthusiasm was the proneness of women to pathologies of reading. According to a political and theological discourse which was widespread in the 1660 s, inspired reading, which was by essence passive, might endanger, not simply the sanity of individual subjects, but in fact the peace of the kingdom: moreover, it was no longer the stridency of female voice which threatened order and stability, but the publication of a private and silent experience. The more spiritual the subject was - and women were reputed to be more spiritual - the weaker the hold of reason in her; to the point where even her senses and no longer only her reason, might be deluded ("In certain individuals (especially women), and in certain circumstances, the images thus presented in the imagination became as strong as those sensed in the outside world - and in such a case the party concerned could scarcely fail to confused the two"

65 As in Samuel Butler's Hudibras and Jonathan Swift's Tale of a Tub. On the controversies around Enthusiasm, see Heyd, 1995. 
(Johns 1998: 417)); "since enthusiasts effectively surrendered their reason to their passions, far from being emancipated by their "visions" as they themselves claim, they were in fact delivering themselves up to merely mechanical reflexes. [...] Enthusiasts were marionettes, "meer Puppets" subjugated to the mechanisms of their bodies" (Johns 1998: 419).

My description has brought to the fore a curious paradox: reading in silence puzzled, fascinated and disturbed eighteenth-century writers and male characters in novels, as it did painters of portraits. But, in accordance to misogynous Renaissance prescriptive ideas - the law of feminine silence-, there should be nothing morally objectionable in silent reading. The eighteenth-century notion, provoking both rejection and titillation, that disturbing things may be taking place in Woman's inner space, inside her, as she reads silently in intimacy, that phantasm would have been most bizarre to an author like Juan Luis Vives.

To recapitulate the points that have been made so far, and also as preparation for the conclusions, I propose to go back to the question of passivity and silence.

Silent reading was, for women, associated from the earliest times with (a) obedience and passivity, but also (b) with ecstatic religious experience. This, according to a long-lived binary, was passive reading. It was tolerated because, being inaudible, it was difficult to monitor and non-injurious to the social order of patriarchy; as a consequence it became, for women, a symbol of piety. The Reformation, in many ways, favoured that development ${ }^{66}$ (as a result of the accessibility of the Bible in the vernaculars, which specifically in England was used as a means of propaganda).

But then religious radicals, including many women from the cultural elites (the gentry, and particularly women from the "middling sorts"), went beyond the mere practice of silent reading and resorted to the "passivity trope" (Gordon 2002: 5-6, 12,22) as a starting point for a vindication of inwardness which made the interiorized "living word" incorporeal and, in effect, autonomous from the Scriptures: thus, passive reading (based on texts in the Christian tradition) was replaced, notably among the Quakers, by a reading - the reception of God's voice immediately - which was productive (sermons, prophecies, visions, etc.) A man, John Rogers, a leader of the millenarian sect of the Fifth Monarchists, made a point far removed from the misogynous theme of the scold: "Your silence may sometimes be the best advocate of your orderly liberty, and the sweetest evidence of your prudence and modesty (...) And yet ye ought not by your silence betray your liberty, trouble your consciences, lose your privileges and rights; or see the truth taken away or suffer before your eyes" (Mack 1992: 107).

The story is one of growing acceptability of passivity - and the experience of intimacy - made possible in part by the evolution of the idea and the actual fact of inner space, which was becoming less and less scandalous or transgressive.

The point made by Scott Paul Gordon is that passive spirituality, and the "passive self", from being the privilege of women, developed to become desirable even for men after $1710^{67}$. This includes as a basic element passive reading.

66 Although it was also to be observed in Catholic cultures; for example, the literature of mysticism in PostTrentine Spain.

67 Michael Gill further explores the connections between passive spirituality and the Cambridge Platonists and to Latitudinarianism. Michael Gill, The British Moralists on Human Nature and the Birth of Secular Ethics (Cambridge: Cambridge University Press, 2006). 
Early modern women, their legal interest subsumed in their husbands', were figured by many discourses as too passionate to be capable of the sort of calculation that interested behavior usually (but not always) implied. The spread of this interestedness, then, extending to all subjects values typically associated with women, supports the claim of several recent scholars that the first "modern" subject was a woman (Gordon 2002: 8).

For many writers, such as the third Earl of Shaftesbury, this passivity still differentiates one individual from another, but it does so along class rather than gender lines; the discourse of sensibility, crucial to many of the texts I investigate, insists that leisured or elite men suffer the same bodily susceptibility from which women were traditionally said to suffer. More crucially, it transforms this passivity into a privilege rather than a curse (Gordon 2002: 9).

The connotations of passivity thus changed: it was no longer so closely associated with "Enthusiasm." In the meanwhile, in an empirical and makeshift fashion, women from the elites - those that could profit most directly from the innovations in interior architecture ${ }^{68}$ - had been cultivating the practice of silent reading:

Against the context of the many restrictions imposed upon women in early modern England, the relative independence and control that privacy offered - made possible by material objects and spaces; chambers and closets, chests and cabinets, locks and keys - was surely of significance to gentlewomen, and should not be obscured by generalized rubrics of private experience as "inescapably" public, or "forever deferred". Private chambers could offer women a degree of personal freedom, self-expression and arguably empowerment which was unavailable to them elsewhere - even as, in different discourses, privacy was used as an ideological tool to marginalize women from "public" life (Roberts 1998: 56-7).

The closet, study and bedchamber offered men and women an intimate and comfortable reading habitat inducive to long hours of uninterrupted and intensive reading, in which they could choose their own company; personal chambers represented distinct sites of reading, differentiated from communal rooms in the home and a marked contrast from an institutional reading space such as the university library. Indeed, the privacy these rooms offered was sometimes deliberately sought out by readers (Roberts 1998: 37).

Active reading - in Anthony Grafton's and Lisa Jardine's commentary on Gabriel Harvey reading Livy (Grafton and Jardine 1990); or in the picture of the "pacification of reading" presented by Steven Zwicker (Zwicker 2003: 295-316) - is precisely reading that adds, reading which produces a new text. But that can be said to put human interpretation on a par with texts that come from God; as an opposite dynamic, affirmation of passivity results in self-denying the reader's text, its nature as the result of textual activity. The "true" interpreter of texts aporetically affirms her passivity and, thus, positively defers to the text; and moreover passivity means that the text is not open, nor added to. Activeness actually came to be seen, by the radical sects, as undermining God's word. So, interpretation necessarily must be inspiration, and the supposed weaker vessel is more readily inspired

68 On this, see Roberts 1998; Laura Gowing, “The Freedom of the Streets': Women and Social Space, 15601640," in Londinopolis: Essays in the Cultural and Social History of Early Modern London, eds. Paul Griffiths and Mark S. R. Jenner (Manchester: Manchester University Press, 2000), 130-51; McKeon 2005. 
precisely because the resistance the reader-interpreter opposes to appropriation by an outer force (i.e. God's) is weaker: nobody is closer to God's scriptures than the passive reader. And a reader can more easily be self-fashioned as passive as a result of silent reading. Only spirituality can come to terms with the imperative of interpretation. Another Fifth Monarchist, this time a woman, Mary Cary, put it thus:

If any shall hereby receive any light [from my prophecies], ... let them bless the Lord for it ... for I am a very weak, and unworthy instrument, and have not done this work by any strength of my own, but have often been made sensible, that I could do no more herein ... of my self, than a pencil or pen can do when no hand guides it; being daily made sensible of my own insufficiency to do anything, as of myself (Mack 1992: 111).

In another tract, Cary, revealingly, went on to say,

Not but that there are many godly women, many who have indeed received the Spirit; but in how small a measure is it? How weak are they? And how unable to prophesy? ... Indeed, they have tasted of the sweetness of the spirit; and having tasted, are longing for more, and are ready to receive from those few that are in any measure furnished with the gifts of the spirit for prophesying; but they are generally very unable to communicate to others, though they would do it many times in their families, among their children and servants; and when they would be communicating to others into whose company they come, though sometimes some dry sprinklings come from them, yet at other times they find themselves dry and barren (Mack 1992: 112).

The phrase "passive reading" is less common than "active reading": simply because of the normative use of "active": reading ought to be active. But to that extent, if "active reading" is desirable, it is because "passive reading" is not just undesirable, but also ontologically prior: the preferred term is the result of correction or overcoming of the less desirable "passive reading", that persistent threat. But, is the reading of Enthusiasm passive? The prophet transcended reading - at the same time denying agency - but called her audience's attention to Scriptural texts, which they were invited to reflect on; what she would have the audience do with them was, in fact, active; except for the fact that the prophet was possessed - that is the meaning of "Enthusiasm" - which is the perfect example of passivity. Thus, passivity produces new texts. In fact, many prophets and preachers opposed the living word to the dead, written text. So, what is left is the claim by radicals that their reading was, we would say today, "passive," but also that what was achieved was the actual creation of new living speech (which was inevitable and welcome since many radicals renounced to the exclusivity of the Christian Scriptures). Enthusiasm, therefore, is creative and passive at once. In Adrian Johns's words,

$[\mathrm{P}]$ eople, whose testimony was either written down by themselves or taken down from their own words, claimed that visions - and inspiration in general - occurred in definite cultural and practical conditions. They particularly stressed their experiences of reading Scripture, and how those experiences changed in the course of their descent into "disease" and transforming ascent into "assurance." In fact, one could characterize their personal experiences as transformations in reading practices. The torpid routines of "book religion" were swept aside as God "irradiated" them directly during their exposure to Scripture. Radicals 
even referred to themselves as possessing an internal "Book of Conscience," "imprinted" by God's spirit to produce their visions. Appropriating mystical, alchemical, and Paracelsian sources, the spoke of the imagination, or "fancy," representing such images to the reason, which could then elaborate them into knowledge. Analyzing their "experiences" of reading thus meant representing states of mind and of the body simultaneously (Johns 1998: 413).

Passivity, though convoluted, is more straightforward: first, many men in the seventeenth century wished to presented themselves as "disinterested", at the cost of being seen as passive (Gordon 2002: 4-6, 11-17); second, women, on the other hand, some of them highly vocal in matters of religion, were supposedly passive by essence, that is, easier to be moved by the power of God. Later, after 1710-1720, the ideology of sensibility and susceptibility came to reinforce that idea, but without the overtones of Enthusiasm.

And passive reading, then? Reading, ideologically is always supposed to be subservient to writing, and reading is always "of writing", including of the "book of nature". The most direct and desirable consequence of reading is more writing: that precisely is the definition of active reading. But the Scriptures, for early modern Christians, were outside that model, because they had not been written, at least not written by an active man. In that case, passive reading may in fact be said to be original. So, essential to the most powerful reading of the seventeenth century is its passiveness.

What this boils down to is the suggestion that women may be better readers of the Scriptures, the intriguing possibility that even semi-literate women may, in some sense, said to be better readers than male scholars. Part of the "world upside down" complex in the 1640s in the British kingdoms included widespread suspicion of intellectual men, some of whom were perceived to be soft on the "innovations" that the Stuart Absolutists tried to impose. In many circles (even in some which were close to the centre of power), the idea was voiced that women were better controversialists because they would not come to blows. However, among other groups the opprobrium against women's speech became, if anything, more violent.

In the picture presented by Christopher Hill and more recently by Post-Revisionist historians like Ann Hughes, it is never claimed, of course, that women in the 1640s, or even in the 1650 s, had an active, independent role in political-religious conflicts ${ }^{69}$. This is the paradox: they could not claim to be - exploit the claim that they were - the "weaker vessel", and at the same time organize themselves independently. Precisely, the denial of agency took the form of the supposed impossibility that women might preserve, beyond conditions of emergency, a place in public discourse. The public voice or public speech of women was one of the ingredients in dystopian representations of the ideological ferment in the Stuart kingdoms from 1637 to 1662, and partly explains why the Restoration of the monarchy in 1660 had such wide popular support. The issue of gender was perceived, in memories and chronicles of the Great Rebellion, as involving imagination, opinion, and

69 Christopher Hill, The World Turned Upside Down. Radical Ideas during the English Revolution (London: Penguin, 1972); Ann Hughes, Gangraena and the Struggle for the English Revolution (Oxford: Oxford University Press, 2004). 
"susceptibility". So, to summarize: non-agency, receptivity to the voice of God, and, specifically, the spiritual influence of the Holy Ghost.

Images of women reading in solitude and intimacy, with their aura of mystery and harmoniousness, but also their incorrigible ambivalence, were a belated side-effect of the utopias of passivity; and the charge of narcissism was an equally belated defence against and compensation for the utopia of inspiration and passivity; the insistence by male painters - an insistence always implicitly moralistic, and sometimes explicitly so - that reading in intimacy was narcissistic and theatrical: for that to be granted, "absorption" should be taken seriously, and the point should be conceded that it was powerful, or even, resorting to etymology, fascinating.

Reference is often made to the reading of women and radicals as interpreters, even voices. But there is a justification, beyond metaphoric use, in speaking of women's reading: the experience of Enthusiasts, of inspired women, always started with the intimate reading of the Bible. If reading is taken as a cultural practice central to the history of the West, we need to explain two issues, which must be taken as blind spots, as ideology: (a) the enduring rapprochement between practices of reading and passivity (the denial of agency, which at times is self-denial), which has made historians and theorists so often insist on an alternative model of reading which is like writing, sometimes described under the cliché of "active reading". Is that a pleonasm? If it is normative it cannot be one; but then if it is normative, it must be opposed to something original conceivable as "non-active reading", and recognizable; (b) the omnipresent and potent gendering of reading, which again thrives on a conceptual confusion: "active reading" is exactly masculine; but then we said before that it was normative, so reading which is not active is prior at least empirically or even conceptually (it is perfectible), in which case "reading not like a man" is the imperfect original.

\section{REFERENCES}

ARASSE, D. 1999. L’Annonciation italienne: une histoire de perspective. Paris: Hazan.

EDWARDS, T. 1997. “Gangraena.” Lay by Your Needles Ladies, Take the Pen: Writing Women in England, 1500-1700. Eds. Suzanne Trill, Kate Chedgzoy and Melanie Osborne. London: Arnold. 151-5.

FLETCHER, A. 1995. Gender, Sex \& Subordination in England 1500-1600. New Haven: Yale University Press.

FREIST, D. 1997. Governed by Opinion: Politics, Religion and the Dynamics of Communication in Stuart London 1637-1645. London: Tauris.

FRIED, M. 1980. Absorption and Theatricality: Painting and Beholder in the Age of Diderot. Chicago: the University of Chicago Press.

GORDON, S. P. 2002. The Power of the Passive Self in English Literature, 1640-1770. Cambridge: Cambridge University Press. 
GRAFTON, A. AND L. JARDINE. 1990. “'Studied for Action': How Gabriel Harvey Read His Livy." Past and Present, No. 129. (Nov., 1990): 30-78.

HACKEL, H. 2003. "“Boasting of Silence': Women Readers in a Patriarchal State." Reading, Society, and Politics in Early Modern England. Eds. Kevin Sharpe and Steven Zwicker. Cambridge: Cambridge University Press. 101-121.

HARRIS, J. G. 1998. Foreign Bodies and the Body Politic: Discourses of Social Pathology in Early Modern England. Cambridge: Cambridge University Press.

HEYD, M. 1995. "Be sober and reasonable." The Critique of Enthusiasm in the Seventeenth and Early Eighteenth Centuries. Leiden: E. J. Brill.

HILL, C. 1972. The World Turned Upside Down: Radical Ideas during the English Revolution. Harmondsworth: Penguin.

HOBY, M. 1997. "Diary.” Lay by Your Needles Ladies, Take the Pen: Writing Women in England, 1500-1700. Eds. Suzanne Trill, Kate Chedgzoy, and Melanie Osborne. London: Arnold. 68-75.

HUGHES, A. 2004. Gangraena and the Struggle for the English Revolution. Oxford: Oxford University Press.

JAMES, S. 1998. "The Passions in Metaphysics and the Theory of Action." The Cambridge History of Seventeenth-Century Philosophy. Eds. Daniel Garber and Michael Ayers. Cambridge: Cambridge University Press. 913-49.

JARDINE, L. 1983. Still Harping on Daughters: Women and Drama in the Age of Shakespeare. Hemel Hempstead: Harvester Wheatsheaf.

JOHNS, A. 1998. The Nature of the Book: Print and Knowledge in the Making. Chicago: The University of Chicago Press.

MACK, P. 1992. Visionary Women: Ecstatic Prophecy in Seventeenth-Century England. Berkeley: University of California Press.

MACLEAN, I. 1980. The Renaissance Notion of Woman. Cambridge: Cambridge University Press.

POCOCK, J. G. A. 2009. Political Thought and History: Essays on Theory and Method. Cambridge: Cambridge University Press.

ROBERTS, S. 1998. "Shakespeare 'creepes into the womens closets about bedtime': Women Reading in a Room of their Own." Renaissance Configurations: voices/bodies/spaces, 1580-1690. Ed. Gordon McMullan, 30-63. London: Macmillan. 30-63.

SALTER, T. 1997. “A Mirrhor mete for all Mothers, Matrones, and Maidens, intitulated the Mirrhor of Modestie." Lay by Your Needles Ladies, Take the Pen: Writing Women in England, 1500-1700. Eds. Suzanne Trill, Kate Chedgzoy, and Melanie Osborne. London: Arnold. 44-50. 
SHARPE, K. AND S. ZWICKER. 2003. "Introduction: Discovering the Renaissance Reader." Reading, Society, and Politics in Early Modern England. Eds. Kevin Sharpe and Steven Zwicker. Cambridge: Cambridge University Press. 1-37.

STAROBINSKI, J. 1964. L'Invention de la liberté. Geneva: Skira.

STUBBES, P. 1997. “A Christal Glass, for Christian Women.” Lay by Your Needles Ladies, Take the Pen: Writing Women in England, 1500-1700. Eds. Suzanne Trill, Kate Chedgzoy, and Melanie Osborne. London: Arnold. 57-62.

WARNER, W. B. 2000. "Staging Readers Reading." Eighteenth-Century Fiction, Volume 12, Number 2-3 (January-April 2000): [392]-416.

ZWICKER, S. 2003. "The Pacification of Reading." Reading, Society, and Politics in Early Modern England. Eds. Kevin Sharpe and Steven Zwicker. Cambridge: Cambridge University Press. 295-316.

\section{SUGGESTIONS FOR FURTHER READING}

GILL, M. 2006. The British Moralists on Human Nature and the Birth of Secular Ethics. Cambridge: Cambridge University Press.

GOWING, L. 1996. Domestic Dangers: Women, Words, and Sex in Early Modern London. Oxford: Oxford University Press.

2000. "The Freedom of the Streets': Women and Social Space, 1560-1640." Londinopolis: Essays in the Cultural and Social History of Early Modern London. Eds. Paul Griffiths and Mark S. R. Jenner. Manchester: Manchester University Press. 130-51

GREENGRASS, M. 2007. Governing Passions: Peace and Reform in the French Kingdom, 1576-1585. Oxford: Oxford University Press.

HIRSCHMAN, A. O. 1977. The Passions and the Interests: Political Arguments for Capitalism before its Triumph. Princeton: Princeton University Press.

HULL, S. 1982. W. Chaste, Silent \& Obedient: English Books for Women 1475-1640. San Marino: Huntington Library.

JAMES, S. 1997. Passion and Action: The Emotions in Seventeenth-Century Philosophy. Oxford: Oxford University Press.

LEVI, A. 1964. French Moralists: The Theory of the Passions, 1585 to 1649. Oxford: Oxford University Press.

MCKEON, M. 2005. The Secret History of Domesticity: Public, Private, and the Division of Knowledge. Baltimore, Md.: Johns Hopkins University Press.

MEYER, M. 1991. Le Philosophe et les passions. Esquisse d'une histoire de la nature humaine. Paris: Presses Universitaires de France. 
OESTREICH, G. 1982. Neostoicism and the Early Modern State. Cambridge: Cambridge University Press, 1982.

SCHOENFELDT, M. 2003. "Reading Bodies." Reading, Society, and Politics in Early Modern England. Eds. Kevin Sharpe and Steven Zwicker. Cambridge: Cambridge University Press. 215-43.

TALON-HUGON, C. 2004. Les Passions. Paris: Armand Colin.

TOULMIN, S. 1990. Cosmopolis: The Hidden Agenda of Modernity. Chicago: Chicago University Press.

TUCK, R. 1993. Philosophy and Government 1572-1651. Cambridge: Cambridge University Press. 